\title{
THE IMPLICIT TAXES FROM COLLEGE FINANCIAL AID
}

Andrew W. Dick

Aaron S. Edlin

Working Paper 5316

\section{NATIONAL BUREAU OF ECONOMIC RESEARCH 1050 Massachusetts Avenue \\ Cambridge, MA 02138 \\ October 1995}

We are particularly grateful for the contributions of Michael Topper. We also thank Tom Kane, James Poterba, John Quigley, Alan Auerbach, and the participants in seminars at U.C. Berkeley and the American Economics Association meetings for their comments. We gratefully acknowledge the research assistance of Eric Emch, Kirsten Landeryou and Bryan Lincoln. Edlin thanks the Academic Senate of the University of California, Berkeley and the Institute of Business and Economic Research for funding this project. This paper is part of NBER's research program in Public Economics. Any opinions expressed are those of the authors and not those of the National Bureau of Economic Research.

(c) 1995 by Andrew W. Dick and Aaron S. Edlin. All rights reserved. Short sections of text, not to exceed two paragraphs, may be quoted without explicit permission provided that full credit, including $\odot$ notice, is given to the source. 


\title{
THE IMPLICIT TAXES FROM \\ COLLEGE FINANCIAL AID
}

\begin{abstract}
Families who heed the "experts'" advice and save for their children's college education typically receive less financial aid. The variation in the net price of college functions as a large tax on savings. College financial aid also functions as an income tax. This paper estimates the size and determinants of these income and asset taxes. We find that the marginal income tax typically ranges from $2 \%$ to $16 \%$ and the marginal asset levy from somewhat under $10 \%$ to as high as $25 \%$. If a typical family chooses to accumulate $\$ 100,000$ in assets rather than consuming these resources, it loses financial aid worth $\$ 10,000-\$ 20,000$.
\end{abstract}

Andrew W. Dick

Department of Political Science

University of Rochester

Rochester, NY 14627
Aaron S. Edlin

Department of Economics University of California 549 Evans Hall \#3880 Berkeley, CA 94720-3880 and NBER 


\section{Introduction}

Parents are bombarded with advice to start saving early for their children's college education. For instance. one bank's advertisement shows footage of a newborn baby superimposed on that baby's hypothetical college graduation in 2016. The message to parents is: open an account and begin to save. or else your child won't be able to go to college.' Financial planners generally concur. and they point to the dramatic increases in college charges over the past two decades, and the fact that many top schools now charge over $\$ 25,000$ for tuition and living expenses. One must keep in mind. though, that such numbers are only "sticker" prices.

Tuition figures do not present an accurate picture of the price of college because many students receive financial aid. The majority of student aid is intended to fill the gap between the cost of college and what parents can reasonably be expected to pay. Because such "need-based" aid typically depends on assets, two families with the same earnings can pay dramatically different prices for college if one saved while the other spent. Ironically, the family that heeds the "experts" advice and saves for college must pay more. The variation in the net price of college functions as a large tax on savings. In a similar way, the fact that those with higher incomes typically must pay more to send children to college is, in effect, an income tax.

Although the taxes implicit in many smaller government aid programs such as Aid to Families with Dependent Children have motivated substantial research efforts, little empirical work investigates the "tax schedules" implicit in the college financial aid process. $^{2}$ This paper fills part of this gap by using the National Postsecondary Student Aid Study (NPSAS 1987) to estimate the size of the income and asset taxes and how they

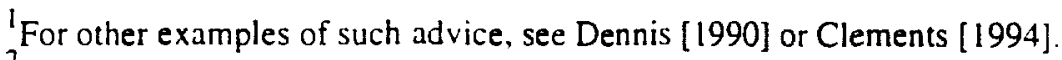

${ }^{2}$ We know of two exceptions. Feldstein [1995], discussed more below, estimates the reaction to these taxes. Also, Venti [1983] estimates that the implicit income taxes from college financial aid are $7.5 \%$. His work differs from ours in that he estimates only average tax rates, or put differently. does not allow marginal rates to vary: he does not estimate asset taxes: and he studies the year 1972. when most financial aid was provided by universities instead of by the federal government.
} 
vary among institutions and among families of different means. These estimates provide insight into two things: first, the size of incentives to alter assets and income; and second, the vertical and horizontal equity characteristics of the financial aid taxes.

Edlin [1993], Feldstein [1995], and Case and McPherson [1986] have recently brought attention to the disincentive to save under the current need-based financial aid system. They calculate that each dollar saved before college may purchase as little as half the consumption that it would without the tax. Such a tax has the potential to induce significant distortions. and in fact, Feldstein has estimated that the parents in his sample would hold $50 \%$ more assets on average were it not for this tax ( $\$ 35.770$ instead of $\$ 23,785)$. Such an estimate is worrisome, particularly to those who already have other reasons to believe that the L.S. savings rate is too low.

On the other hand, the taxes that Feldstein. Edlin, and Case and McPherson calculate may be poor approximations of the true implicit taxes from financial aid. because they are not based on the aid students actually receive. Instead, these authors assume that aid covers the entire difference between college cost and the student's "Expected Family Contribution" (EFC), i.e. what a particular family can reasonably be expected to pay according to Department of Education guidelines. ${ }^{3}$ In fact, aid does not generally cover all of this so-called "need". The federal formulas to determine need are a safeguard to ensure that federal support does not go to those who don't need it. They do not create an entitlement to have all need met with aid, and federal programs do not stand ready to dole out enough subsidized aid to meet the need of all students. ${ }^{4}$ Colleges have the discretion to fill any remaining gap as they choose, but most are not committed to supplement federal funds to meet all of the residual need. ${ }^{5}$ This fact could cause skeptics

\footnotetext{
${ }^{3}$ For a description of how EFC is defined, see Edlin [1993].

${ }^{4}$ For example, during the 1994-95 academic year, if a student's EFC was greater than $\$ 2,100$, the student was not eligible for a Pell grant, regardless of her need. See "Federal Pell Grant Program Schedule for Determining Full-Time Scheduled Awards for the 1994-95 Award Period," United States Department of Education.

${ }^{5}$ Peterson's $199 /$ College Honey Handbook lists institutions that are committed to meeting all need.
} 
to doubt that aid taxes are significant at all, and certainly brings into question the above estimates.

Our empirical work uses data on aid awards to estimate the marginal tax rates families actually face. We find that a one dollar fall in EFC does not generally lead to an extra dollar in aid. In fact, the difference in aid depends upon the type of school the student attends and her family's means. The marginal income tax ranges from $2 \%$ to $16 \%$ and the marginal asset levy from somewhat under $10 \%$ to as high as $25 \%$ for typical families. These asset taxes are not as large as those calculated directly from federal need determination formulas; nonetheless, they are large enough to raise concerns about the horizontal equity of the financial aid system. ${ }^{6}$ Two families with the same lifetime income may wind up paying vastly different prices for college. If a typical family chooses to accumulate $\$ 100,000$ in assets rather than consuming these resources, it loses financial aid worth $\$ 10,000-\$ 20,000$.

At the same time, the variation of tax rates with means raises questions of vertical equity. The federal need determination formulas are designed to use increasing marginal tax rates to determine what a family can be expected to pay (EFC), a tax system we refer to as "progressive". 7 On the other hand, the correspondence we estimate between EFC and the aid a student is ultimately awarded tends to make the overall marginal tax rate decline with means, a characteristic we refer to as "regressive". 8 In other words, families with low means find that more of their aid is taken away for a given increase in income or assets than would be taken from a family with high means. Interestingly, when Feldstein

\footnotetext{
${ }^{6}$ Feldstein [1994], commenting on capital income taxation attests that "any fair system of income taxation should be based on the principle that two similar individuals with the same income should pay the same tax."

${ }^{7}$ According to the Department of Education [1990]: "The rate is based on the principle that as income increases beyond the amount needed to maintain a basic standard of living, the portion used for family maintenance decreases, while the port' $2 n$ available for discretionary purposes increases." ( $\left.\Gamma_{\text {ornula }} \mathrm{A}-2 \mathrm{C}\right)$.

${ }^{8}$ One can alternatively define "progressivity" and "regressivity" as increasing and decreasing average tax rates, respectively. Where marginal rates are everywhere decreasing or everywhere increasing. the two definitions coincided. For many of the tax schedules we estimate. the distinction is unnecessary and the choice of definitions is irrelevant.
} 
[1995] estimated the impact of these taxes, he assumed the reverse. and this assumption was critical since he estimated the impact of aid taxes on asset holdings by comparing the holdings of families facing different marginal tax rates. Our findings, therefore, reopen questions about the extent to which aid taxes discourage families from accumulating assets.

We also investigate the role played by the source of aid (federal government or institution) and the type of aid (grant or loan). We do this by disaggregating aid into its components and estimating the financial aid taxes generated by each component separately. We find that one dollar of additional earnings or savings leads to a greater reduction in federal aid for a family of low means than for a family of high means. Institutional aid, in contrast, has the opposite pattern. In net, the regressive allocation of federal aid outweighs the progressive allocation of institution aid so that the aid system is regressive overall. When we disaggregate financial aid by type and estimate separate tax schedules resulting from the distribution of grants and loans. we find that most of the taxes come from a reduction in grants, and little of the taxes come from a reduction in loans.

The remainder of this article is organized as follows. Section 2 provides an overview of the student financial aid system. Section 3 discusses the NPSAS data set. Section 4 explores the relationship of expected family contribution to the aid a student receives. Section 5 estimates the full determinants of aid and uses these estimates to calculate implicit marginal tax rates on income and assets. Section 6 investigates the rote played by different sources and types of aid and calculates the implicit marginal tax rates associated with each. Section 7 discusses the implications of the results.

\section{Overview of the Financial Aid System}

In the 1994-95 school year the Student Financial Assistance programs administered by the U.S. Department of Education disbursed $\$ 27$ billion in financial aid 
to 6 million students, an average of $\$ 4,500$ per student. This aid accounts for 70 percent of all student aid. ${ }^{9}$ Both now and in the 1986-87 school year. for which we have data, the primary types of federal aid are Pell grants. Supplemental Education Opportunity grants, Stafford loans, PLUS loans, Supplemental Loans for Students. Perkins Loans, and Federal College Work Study. The federal government subsidizes federal loans by paying interest and guaranteeing principal. Until the recent Federal Student Overhaul Program. these loans were issued by private banks, but this program will ultimately phase out the role played by banks in the hope that direct government administration will lower costs. ${ }^{10}$

When parents seek federal financial aid to send dependent children to college they must fill out the Free Application for Federal Student Aid (FAFSA). If they seek institutional aid, the institution usually requires them to fill out the Financial Aid Form (FAF) and send it to the College Scholarship Service. These forms request information such as the parents' income, assets. and number of children.

The "Central Processing System" at the Department of Education uses the information on the FAFSA to generate a summary statistic representing what the parents can afford to pay for college. This figure is divided by the number of college students in the family and then added to any given student's own contribution. The result is the Expected Family Contribution (EFC) to that student's education, a figure reported to the colleges. EFC is intended to measure what a family can reasonably be expected to contribute to a child's education. A student's financial need is defined to be the difference between the cost of attending a given college and EFC. In principle, therefore, these figures are all that a financial aid officer needs to know to determine need-based aid. However, in addition to this summary statistic, colleges can get the raw data from which the EFC is calculated. Typically, the colleges also require parents to submit their IRS

\footnotetext{
${ }^{9}$ U.S. Department of Education [1994], p. 8.

${ }^{10}$ U.S. News \& World Report [1994], p.70.
} 
1040s, which they can use to check the honesty or accuracy of the "estimated" data on the FAFSA.

For each student, the college assembles an aid package which may include federal subsidized loans, federal grants, federal work-study, and aid provided by the state or the college itself. If the college gives a student too much aid, so that she no longer has need. she will not be eligible for federal grants or other subsidized programs. "

One of the important changes of the 1992 Higher Education Act was the exclusion of home equity from the federally required financial aid form. However. many colleges require parents to fill out the FAF. which requires them to report the year they bought their home, the price at which they purchased it, its current value, and the amount owed on it. Thus, this information may still enter into a college's aid decisions.

\section{The National Postsecondary Student Aid Survey (NPSAS)}

We use data from the 1987 National Postsecondary Student Aid Survey (NPSAS). This survey, conducted by the Department of Education, is a nationally representative sample of post-secondary students enrolled in Fall 1986. It provides financial aid, school cost, and family background data on about 43,000 students from institution. student, and parent surveys. The Fall 1986 survey was updated in 1987 to account for changes in financial aid during the academic year. Institutional records are available only for students who applied for financial aid and thus filled out appropriate financial aid forms. Since these data are the most reliable, and the student and parental survey data are poor, we restrict our study to applicants. ${ }^{12}$

\footnotetext{
"Today a student without need may be eligible for unsubsidized Federal Stafford or PLUS loans, provided the total amount of aid does not exceed the college's cost of attendance (including tuition and fees, an allowance for living expenses, books and supplies and transportation costs). U.S. Department of Education [1994] p. 12. This was not true in the 1986-87 school year that we study.

"See U.S. Department of Education [1993] for an analysis of the reliability of data from the various NPSAS modules.
} 
We further restrict our sample to applicants who are dependent citizens and eligible non residents attending four-year colleges and universities. This leaves us with 10,490 observations.

\subsection{Definition of Variables}

NPSAS identifies financial aid according to its source (federal, state, institutional, or other) and according to its type (grant, loan, work study, or other). For each student we form two measures of aid. TOTAL AID is the sum of grants, loans, work study and other. This is the measure of aid usually referred to when "total aid" figures are quoted (such as the figure cited earlier that $\$ 27$ billion of aid will be disbursed by the federal government in the 1994-95 school year). AID VALUE, on the other hand, is defined to be grants plus one-half of loans, and is intended to capture the value of aid.

In practice, of course, the value of loans varies substantially. It depends upon the interest rate, the date interest payment begins, and the term of the loan. Federal loans typically have below-market interest rates and accrue no interest as long as students remain in school. Institutional loans have widely varying characteristics. It is therefore very difficult to determine the extent to which loans should be discounted. We choose to value a one dollar loan at fifty cents. ${ }^{13}$ As discussed in Section 6, however, this choice does not affect our estimates dramatically.

Expected Family Contribution (EFC) is the amount that the Student Aid Methodology determines a family can reasonably be expected to pay to send a child to college given the family's assets, income, and demographic characteristics. For each student, the National Center for Education Statistics calculates the EFC using the 1986-87 Family Contribution Formula of the Office of Student Financial Aid, Department of Education.

\footnotetext{
${ }^{13}$ This figure is from McPherson and Schapiro [1991]. Feldstein [1995] estimates that a one dollar loan was worth sixty cents given the terms of loans and the interest rates in 1985. one year prior to the year we study.
} 
Our variable for the cost of attendance at an institution (COST) inclucs tuition and fees together with an allowance for living expenses as determined by the federal student aid methodology. Living expenses include books and supplies, room and board. health care insurance and transportation. ${ }^{1+}$ When we speak of "need," we mean COST less EFC. As described below, most of our empirical results are limited to students who have need.

We also have data on a family's income and assets. Income was measured as the parert's 1986 adjusted gross income plus untaxed income. Tota! assets include finutscial assets, housing equity. ${ }^{15}$ business equity. plus equity in other investments. Pensions and retirement accounts are excluded from the federal need determination formulas and fron: our measure of assets.

Finally, we have variables representing sex, race, age. residency status, marital status, and whether a student applied for aid.

\subsection{Financial Aid Summary Statistics}

Tables 1 and 2 contain aid breakdowns by income and assets based on our two measures of aid, TOTAL AID and AID VALUE, as described above. Although the relationships are not perfectly monotonic, the tables reveal a strong tendency for both TOTAL AID and AID VALUE to decline with income and assets.

One could naively calculate the financial aid taxes on income and assets from these tables. Families with incomes between $\$ 50,000$ and $\$ 60,000$ receive financial aid worth $\$ 1,878$ less per year than families with income between 0 and $\$ 10,000$. This suggests an income tax of $3.7 \%$. Similarly, those with assets of $\$ 50,000-\$ 60,000$ receive $\$ 1,514$ less aid per year on average than those with assets of $0-\$ 10,000$. Since assets are a stock, not a flow, this reduction should be multiplied by the number of years a

\footnotetext{
${ }^{14}$ See e.g. U.S. Department of Education [199.4], p. 10.

${ }^{15}$ In 1986-87. home equity was included in the financial aid formula: thus we include it in our measure of assets.
} 
typical family has children in college. Assuming two children go to college sequentially for 8 years the total loss in aid may be $\$ 12.112$. This suggests an asset levy of $24 \%$, a figure only somewhat lower than the $30-50 \%$ that Feldstein estimates from federal formulas.

We cannot, however, realistically infer the tax on asset accumulation from such a calculation, because it tends to overestimate the tax on assets in terms of reduced aid -families with high assets probably also have high income and much of the "tax" is really, therefore, a tax on their income. On the other hand, it may actually understate the financial aid tax because it does not account for heterogeneity in school choice and family characteristics. For instance, aid awards at private colleges are approximately twice as high as those at public colleges. ${ }^{16}$ If high-means families tend to go to private colleges we might calculate a low "tax" rate even though. holding school fixed. the budget constraint trading off pre- and post-college consumption is quite steep. Likewise, consider heterogeneity among families. Those with high means who apply for aid will be disproportionately likely to have multiple children in college at once, because this tends to make them needy. Comparing the aid they receive with the aid of a lower means family with fewer children does not yield the tax rate c.l either family; it biases the measured tax rate downward. We must run multivariate regressions since we seek answers to questions such as: How much would an increase in assets lower aid for a family sending a child to a private college with tuition of $\$ 3,000$ ?

\section{Expected Family Contribution and Aid}

This section explores the empirical relationship between a family's expected family contribution (EFC) and the college financial aid their children receive. We address four questions. Do colleges fully meet need? Do colleges meet $100 \%$ of

\footnotetext{
${ }^{16}$ McPherson and Schapiro [1991]. p. 7 .
} 
marginal need? What is the relationship between aid and EFC? Finally, what are the vertical equity implications of the results?

We start with a simple model in which EFC fully captures the impact on aid of assets, income, and other factors. That is, we assume aid is fully determined by EFC and COST, so that colleges do not consider any other information in determining how much aid to provide in addition to federal aid. In Section 5, we check this assumption. In any event, we expect EFC and aid to be strongly related because most colleges want to charge lower prices to families with lower means. ${ }^{17}$ Moreover, it is probably easier for them to free ride on the effort of the federal government in developing the formula for EFC and calculating EFC for each student. Even if college financial aid offices develop systems of determining means from scratch, the outcome of those systems would most likely be highly correlated with EFC.

Feldstein [1995] assumes that financial aid is an affine function of need given by

AID VALUE $=C+\alpha *$ need, where need $=(\operatorname{COST}-E F C)$

In a system where aid is determined entirely by need and is enough to meet all need, $C=0$ and $\alpha=1$. ( $\alpha$ actually would be lower if some aid came as loans.) $\mathrm{C}$ may be nonzero for several reasons. Merit aid, for instance, might cause $C$ to be positive. Even in the presence of merit aid, however, it would still be possible that an extra dollar of need always raises the value of aid by one dollar, so that $\alpha$ equals 1 .

The calculations by Feldstein [1995] and Edlin [1993] of financial aid tax rates presuppose that $\alpha$ is nearly 1, as do Edlin's [1992] simulations estimating the potential impact of the taxes on savings. Feldstein's empirical estimates of the impact of the taxes

\footnotetext{
${ }^{17}$ In part, this discrimination in price may be an effort to capture consumer surplus, but it also results from a genuine concern about vertical equity and "keeping college affordable." Note the prominent usage of this phrase in sources as diverse as campaign literature and academic writing. For example. see Brown [1994] and McPherson and Schapiro [1991].
} 
on savings are not, however, so sensitive. His estimates are valid no matter what value $\alpha$ takes. Nonetheless the aid process must match (1) for his estimation procedure to be sensible. ${ }^{18}$

We estimate a more general specification, of which (1) is a special case. This allows us to test the joint hypotheses that $\mathrm{C}=0$ and $\alpha=1$, implying schools meet all need. It also allows us to test the hypothesis that $\alpha=1$, implying that 100 percent of marginal need is met. In addition, we can test the hypothesis that $\alpha$ is constant over different values of need. If we reject this hypothesis, we would be forced to abandon (1). This would suggest revisit:- $\underset{g}{=}$ Feldstein's work that estimates the impact of the implicit taxes on savings.

The last hypothesis has direct consequences for vertical equity. For instance, if families with higher EFC have a smaller fraction of their need met, this might imply that they have lower marginal tax rates on income and assets than do families with lower means. Although the EFC formula is designed to be highly progressive, if the rate at which marginal need is met with aid declines sufficiently with means. the overall implicit tax schedule of the financial aid system can be regressive. This could occur for at least two reasons. The nominal amount of financial aid awarded to relatively high means families may be insensitive to their means. Alternatively, the value of their aid packages might be more insensitive if their aid packages have a larger share of loans to grants.

Because of the importance and likelihood of these possibilities, our empirical specifications must be flexible enough to admit nonlinear relationships between EFC and the value of aid. The specifications we use lead us to reject all the hypotheses discussed above. We find that the rate at which higher EFC lowers aid depends on the type of institution attended (public or private), the cost of the institution, and upon EFC itself.

\footnotetext{
${ }^{18}$ Feldstein's procedure uses the variation in the tax rates in the federal formulas (which determine EFC) to estimate the impact of these taxes. For this method to be sensible, the true tax rates must be proportional to those in the formulas (e.g., $\alpha$ must be constant and not a function of EFC).
} 


\subsection{Empirical Specification}

In our general specification, we do not restrict the coefficients on EFC and COST to be equal and opposite in sign, nor do we restrict the relationship between AID and EFC to be linear. Thus, we estimate models of the form

$$
\begin{gathered}
\text { AID VALUE }=C+\beta_{1} E F C+\beta_{2} \operatorname{COST}+\beta_{3} \mathrm{EFC}^{2}+\beta_{4} \mathrm{COST}^{2}+\beta_{5} \mathrm{EFC}^{*} \mathrm{COST}+ \\
\beta_{6} \mathrm{EFC}^{3}+\beta_{7} \mathrm{COST}^{3}+\varepsilon .
\end{gathered}
$$

The second and third order terms allow AID to vary nonlinearly with EFC and COST. The interaction term allows the relationship between EFC and AID to vary at different levels of COST. If the coefficients on the second and third order terms and on the interaction term are restricted to zero, and if the coefficients on the first order terms are restricted to be equal and opposite in sign, (2) becomes (1). Thus, (2) allows us to test the assumptions made by Edlin [1993] and Feldstein [1995].

Because some students in our sample do not receive any financial aid, we also estimate a tobit model of the form

$$
\begin{aligned}
& \text { AID VALUE }{ }^{*}=C+\beta_{1} E F C+\beta_{2} \mathrm{COST}+\beta_{3} \mathrm{EFC}^{2}+\beta_{4} \mathrm{COST}^{2}+ \\
& \qquad \beta_{5} \mathrm{EFC}^{*} \operatorname{COST}+\beta_{6} \mathrm{EFC}^{3}+\beta_{7} \mathrm{COST}^{3}+\varepsilon \\
& \text { AID VALUE }=\text { AID VALUE }{ }^{*} \text { if AID VALUE }{ }^{*}>0 \text { and } \\
& \text { AID VALUE }=0 \text { otherwise. }
\end{aligned}
$$

We assume $\varepsilon$ is a normal i.i.d. random variable with mean $\mu$ and variance $\sigma^{2}$. We restrict the sample to aid applicants who are full-year and full-time students and who have positive need, i.e. applicants for whom EFC $<$ COST. This leaves us with a sample containing 6,537 students. We also allow the relationships to differ for public and private institutions by estimating (2) and (3) separately for each. Table 3 contains summary statistics for this sample. 


\subsection{Results}

Table 4 contains parameter estimates of (2) and (3). Columns 1 and 2 are for private institutions while 3 and 4 are for public institutions. We test down to eliminate regressors that are not significantly different from zero at the $5 \%$ level. For purposes of comparing the results in this section with those in Section 5, however, we retain regressors that are significant in either set of regressions. This eliminates the EFC 3 term from the private school regressions and $\operatorname{COST}^{3}$ from the public school regressions. The rest of the regressors. however, give significant predictive power.

We strongly reject the model given by (1) for both yublic and private institutions. ${ }^{19}$ We also reject the hypothesis that the relationships are the same for public and private institutions. Thus, the effect of an increase in EFC on the value of aid depends upon whether a student attends a public or private school, the cost of attending the school, and the level of EFC.

Because the coefficients on the interaction term EFC*COST are consistently different from zero, the implicit tax rates at high priced schools are different from those at low priced schools. Because EFC is an increasing function of assets and income and because the estimated coefficients on EFC*COST are consistently negative, the corresponding implicit tax rates are higher at higher priced schools. The effect is economically as well as statistically significant: at private institutions, a $\$ 5,000$ higher cost will result in an extra 5\% marginal tax on capital and an extra $2.5 \%$ marginal tax on income for the typical family. ${ }^{20}$ For public institutions, the extra capital levy is even higher.

\footnotetext{
${ }^{19}$ For public schools, the likelihood ratio statistics are 146.4 and 130.2 for the OLS and tobit models, respectively. For private schools, the likelihood ratio statistics are 119.0 and 118.8 for the OLS and tobit models, respectively. Each of these statistics is distributed chi-squared with 6 degrees of freedom. Therefore. we easily reject the restrictions implied by the model in (1).

${ }^{20}$ The coefficient on the interaction term is -.00002 . When multiplied by $\$ 5,000$ this yields a $10 \%$ marginal tax on EFC. Suppose a family has a state and federal marginal tax rate of $40 \%$ and is in a $40 \%$ marginal tax bracket in the student aid system as well. Then each dollar of income increases EFC by about 25 cents. If assets earn $3 \%$ after taxes they raise EFC by 6 cents per year. Assuming children are in college for 8 years, the asset levy is $1 / 2$ the tax on income.
} 
The fact that the coefficients on EFC 2 are positive and significant means that higher means families have a lower marginal EFC-tax. These results are economically important for both public and private institutions. Figure 1 plots the negative of the derivative of AID VALUE with respect to EFC for public and private schools for families attending schools of average $\operatorname{cost}^{2 !}$. These graphs show the rapidly decreasing marginal tax rate as EFC rises. This unwinds the progressivity that was purposefully built into the federal EFC formulas. Federal formulas construct a measure of what a family will be able to pay for college imagining that families with higher means can spend a larger fraction of each extra dollar on college. However. as Figure 1 illustrates, this progressive goal is confounded by the actual allocation of aid: in response to a one dollar increase in EFC, the value of aid awards falls by more for families with low means than for those with high means. Thus, while conventional notions of vertical equity were built into the formulas determining financial need, the aid award process tends to be regressive.

These findings need to be taken into account to properly estimate the impact of aid taxes. Consider, for example, Feldstein [1995], who estimated the impact of aid taxes on asset holdings by comparing the holdings of families facing different marginal tax rates. Families who he identified as having lower marginal tax rates tended to have higher asset holdings, so he concludes that aid taxes reduce asset holdings. He calculated tax rates using the federal need determination formula, however, so he assumed that for families with positive financial need, higher means implies higher marginal tax rates. Yet if higher means families in fact face lower marginal tax rates, as we estimate, then this could significantly change the results of his regressions. It would seem to imply that higher aid taxes actually increase asset holdings. However, there is a complication. Families with very high means in Feldstein's study have no financial need; these families pay full tuition and so have no marginal taxes. If his results stemmed from the different

\footnotetext{
${ }^{21}$ The average cost at public schools in our sample is $\$ 5,070$. For private schools it is $\$ 10,783$
} 
savings patterns between low means families and very high means families, then changing the marginal tax rates in his regressions could actually accentuate his results.

\section{Taxes Outside Federal Formulas}

The previous section maintained the hypothesis that EFC contains all the information about a student and her family that is relevant for predicting the aid she receives. Thus, the specifications in Section 4 controlled only for EFC, COST, and whether the college or university was public or private. Such an assumption need not hold, of course. Colleges know the financial standing of the student's family and can create their own aid formulas (as long as they don't use federal funds to give aid to students without need).

Therefore in this section we include parental income and parental assets separately (apart from their implicit inclusion in EFC). We estimate a specification of the form

$$
\begin{gathered}
\text { AID VALLE }=C+\beta_{1} E F C+\beta_{2} \operatorname{COST}+\beta_{3} E_{F C}^{2}+\beta_{4} \operatorname{COST}^{2}+\beta_{5} E_{F C}^{*} C \text { OST }+ \\
\beta_{6} E C^{3}+\beta_{7} \operatorname{COST}^{3}+\gamma X+\varepsilon,
\end{gathered}
$$

where $\gamma$ is a vector of coefficients and $X$ is a matrix of covariates that includes parental assets, parental income, a student's race, residence, ethnicity and sex. Because parental asset information contains missing values, our samples are restricted to 3,180 observations and 1,668 observations for private and public schools, respectively. Table 3 contains summary statistics for the sample. ${ }^{22}$

\footnotetext{
${ }^{22}$ We estimated the specifications from Section 4 with this sample and compared the results to those from Section 4 . The results were similar, suggesting that the missing data does not cause a large selection effect.
} 
As above, to account for those students who received no aid. we estimate tobit specifications of the form

$$
\begin{aligned}
& \text { AID VALUE }{ }^{*}=C+\beta_{1} E F C+\beta_{2} \operatorname{COST}+\beta_{3} \mathrm{EFC}^{2}+\beta_{4} \mathrm{COST}^{2}+ \\
& \beta_{5} \mathrm{EFC}^{*} \operatorname{COST}+\beta_{6} \mathrm{EFC}^{3}+\beta_{7} \operatorname{COST}^{3}+\gamma \mathrm{X}+\varepsilon \\
& \text { AID VALUE }=\text { AID VALLE } * \text { if AID VALLE }>0 \text { and } \\
& \text { AID VALLE }=0 \text { otherwise. }
\end{aligned}
$$

Again, to allow for different relationships in public and private institutions, we estimate $\left(2^{\prime}\right)$ and ( $\left.3^{\prime}\right)$ separately for public and private institutions.

\subsection{Results}

Table 5 presents parameter estimates for (2) and (3'). The first two columns contain the results for private institutions and the last two. the results for public institutions. The OLS and tobit results are quite similar. As in Table 4, the EFC terms are important predictors of aid; however, the coefficients on many asset categories and income are also significantly different from zero. The likelihood ratio test statistic for the hypothesis that the new parameters are jointly zero is greater than 160 , strongly rejecting the model in the previous section. ${ }^{23}$ Most of the improved fit is due to the financial variables, so we are extremely confident that these variables enter the aid determination process apart from their entry in the federal formula's ability-to-pay measure, EFC.

In the present formulation, an increase in a family's assets may affect aid in two ways: through a particular asset's direct entry into the regression equation, and through its effect upon EFC. The same is true of income. Figure 2 shows the yearly rate at which increases in money asset holdings reduce the value of aid for typical families in our

\footnotetext{
${ }^{23}$ We calculate the likelihood ratio statistics using the models of Section 4 (re-estimated with the sample from Section 5) as the restricted models and the models of Section 5 the unrestricted models. For the OLS and tobit specifications at public schools, the likelihood ratio statistic equals 200.2 and 203.6. respectively. The likelihood ratio statistics for private schools. calculated in an analogous manner to those for public schools. are 162.6 and 172.0 for the OLS and tobit models. respectively.
} 
samples. $^{24}$ The rates depicted for private (respectively, public) institutions assume income and holdings of other assets equal to the averages for families sending children to private (respectively, public) institutions. The saw-tooth pattern results from the tension between the progressivity in the federal formula that determines EFC and the regressivity from the way marginal need is met with aid (see Figure 1). ${ }^{25}$ Estimates of the coefficients on the EFC terms indicate that families with higher means (but who are still eligible for need-based aid) tend to face lower marginal tax rates. Algebraically, this effect stems from the positive coefficient on EFC 2 . In terms of financial aid policy, it probably stems from federal aid programs meeting a larger share of need when need is large, or equivalently offering a larger share of grants in any given aid package. This produces the tendencies at both public and private institutions for the marginal tax rates to fall as assets increase. The upward spikes result from switching "tax" brackets in the federal need determination formulas. By design, these switches tend to make the tax system progressive.

At public institutions, the regressive tendencies dominate, so the marginal tax rate falls from $3.2 \%$ per year at assets of $\$ 1,000$ to about $1.5 \%$ at assets of $\$ 80,000$. Over 8 years, the corresponding fall is from a marginal asset levy of about $25.6 \%$ on those with low assets to one of $10.4 \%$ on those with high assets.

At private institutions, in contrast, the progressive tendencies dominate, at least to a point. However, after parents hold approximately $\$ 35,000$ in cash assets the top marginal asset tax is reached (roughly $3.1 \%$ ) and then the marginal tax rate begins to fall steadily as cash holdings increase. As with the public institutions, the pattern is created

\footnotetext{
${ }^{24}$ By "typical" we mean holding earned income, home equity, other assets, and business assets at their mean values. We also hold costs at mean values. At private schools, the mean earned income in our sample is $\$ 30,752$ : mean levels of home equity, other assets, and business assets are $\$ 35,152, \$ 7,326$, and $\$ 4,211$, respectively; and the mean level of costs is $\$ 10,783$. At public schools, the mean earned income is $\$ 21,150$; the mean levels of home equity, other assets, and business assets are $\$ 22,841, \$ 3,059$, and 4,246 , respectively; and the mean level of cost is $\$ 5,043$.

25 The deviate of AID VALUE with respect to EFC looks similar for the specification here as for the specification in Section 4 that is graphed in Figure 1.
} 
by the estimated coefticients on the EFC terms, and thus holds for each of the assets and for income. At $\$ 100,000$ in cash assets, the marginal asset levy is about $1.9 \%$. Assuming two children go to college sequentially for 8 years, the corresponding marginal asset levies are $24.8 \%$ and $15.2 \%$ at $\$ 35,000$ and $\$ 100.000$ in cash assets. respectivaly. The "additional tax" resulting from the coefficient estimates on the asset or income terms simply shifts the marginal tax level up or down depending on the magnitude of the specific assets coefficient. If an asset does not bear explicit interest. the tax through the EFC terms will also decrease somewhat (in the figure, approximately one quarter of the tax from the EFC terms comes from an assumed $5 C_{c}^{\circ}$ rate of interest 1.

These taxes can lead to substantial variation in the prices families pay for college. Consider. for instance, two families as depicted in Figure 2. who differ only in the amount of cash assets they have accumulated. If both families send children to private schools, but one accumulates the mean level of cash assets in our sample $(54,476)$. while the other accumulates an additional $\$ 100.000$ in cash assets, they will receive aid worth $\$ 5,570$ and $\$ 2,974$, respectively. Over four years this difference would amount to nearly \$10,400 and over eight years it would total nearly $\$ 20,800$. For families who send their children to public schools, the difference is less stark. Again. for two typical families who send children to public schools, one who accumulates the mean level of cash assets in our sample $(\$ 2,536)$ and one who accumulates an additional $\$ 100,000$ in cash assets, the difference in the value of aid they receive would be $\$ 8,588$ over four years and $\$ 17,176$ over eight years. These tax rates are only somewhat lower than the unconditional tax rates calculated in Section 3.2.

Figure 3 contains plots of the estimated marginal tax rate on income for families with characteristics identical to those in Figure $2{ }^{26}$ The characteristics of the income tax are similar to those of the assets tax, however, the annual rate is substantially higher. For

\footnotetext{
${ }^{26}$ In addition to those characteristics held constant in figure 2. we set cash assets at mean levels in figure 3. The mean values of cash assets were $\$ 4.476$ and $\$ 2.536$ for private and public schools. respectively.
} 
the families depicted in the figure, the federal need determination formulas disregard income below about $\$ 12.000$. This explains why the marginal tax rate is flat at $2 \%$, when income is low. At public schools, as these families' income exceeds \$12.000, the marginal tax rate jumps to almost $16 \%$ and then rapidly falls to zero as income approaches $\$ 40,000$. The progressive component built into the tax directly by the federal need determination formulas is barely apparent because of the strong regressive nature of the income tax actually imposed through the allocation of aid in practice. The unconditional income tax levy, which in Section 3.2 we estimated to be $3.7 \%$, is at the low end of the marginal tax rates in our estimated schedule for public institutions.

For private institutions, the progressive component, represented by the upward spikes in the saw-tooth pattern, keeps the marginal income tax rate between $7 \%$ and $10 \%$ until family income reaches $\$ 40,000$. At that point, however, family income has reached the highest tax bracket as defined by the federal need determination formulas. Beyond $\$ 40,000$, the regressive component of the tax, which results from the use of EFC in practice, dominates. The marginal tax rate falls from a high of about $10 \%$ around $\$ 40,000$ of income to less than $4 \%$ at $\$ 60,000$ of income. From $\$ 12,000$ to $\$ 60,000$ of income, the estimated income tax schedule for private institutions always exceeds the unconditional rate of $3.7 \%$, estimated in Section 3.2 .

The coefficients on the cost terms also have important interpretations. The derivative of aid with respect to cost gives the marginal subsidy for educational expenditures. Suppose a family chooses to buy $\$ 1,000$ in extra education (more expensive college). The net price increases by less than the full $\$ 1,000$, because the financial aid system provides a subsidy for marginal educational expenditures. Figure 4 contains graphs of the subsidy as college costs change, again, for typical families in our samples. For students who attend private colleges with costs up to about $\$ 12,000$, the marginal subsidy increases at higher priced colleges as indicated by the positive coefficient on $\operatorname{COST}^{2}$. Above $\$ 12,000$, the marginal subsidy decreases at higher priced 
‥lleges because the negative coefticient on the COST 3 term dominates. For average priced private colleges (priced at \$10,000), the marginal subsidy for expenditures is about 45\%. For students who attend public colleges, the marginal subsidy decreases at higher priced colleges due to the negative coefficient on COST 2 . For average priced public colleges (priced a: 55.000 ), the marginal subsidy for expenditures is about $14 c^{c} \mathrm{c}$.

The negative coefficient on the interaction term (EFC*COST) indicates that marginal subsidies are higher for families with low means ifumilies with EFC of $\$ 5,000$ will have a subsidy that is ten cents on the dollar less than a family with an EFC of $\$ 0$ ). This feature meets a fundamental goal of financial aid. which is to provide particular encouragement for the poor to consume extra education.

\section{The Composition of Aid}

This section explores the differences in the financial aid taxes implicit in institution-awarded aid from those implicit in federal aid awards. Knowledge about how these sources affect the total financial aid tax is important for two reasons. First. it may help us to assess the impact of the rules governing the allocation of federal monies and modify them accordingly. Second, we can assess the role of institutionally provided aid, and determine whether it is confounding the goals of federal aid policies. Therefore, in this section, we investigate the characteristics of the financial aid taxes by the source of aid. We also explore the breakdown of the implicit taxes into taxes from loans and from grants.

To begin, we estimate ( 2 ') twice, first redefining the dependent variable to be the value of federal aid (Fed_Aid), and then redefining the dependent variable to be the value of institutional aid (Inst_Aid). These sources of aid are not exhaustive, and, as a result, the estimated equations do not sum to the results found in Table 5. They do, however, comprise the vast majority of aid, so summing the estimated equations does closely approximate the previous results. 
Figure 5 shows the marginal asset tax rates implied by these estimates by source. for a typical student at private schools and for a typical student at public schools. ${ }^{27}$ The difference in the character of the marginal tax rates by source is stark. At public schools, the marginal asset tax rates from federal aid are considerably higher than those from institutional aid. This is especially true for families with low levels of cash assets, for whom the marginal federal aid tax peaks at about $3 \%$ per year, while the marginal institutional aid tax increases from about $0 \%$ per year to about $0.5 \%$ per year as cash assets increase from $\$ 0$ to $\$ 80,000$. In addition, the marginal asset tax rates resulting from federal aid are highly regressive, falling considerably as means increase, whereas the taxes from institution aid are progressive. In net, however, the regressivity of the allocation of federal aid outweighs the progressivity of institution aid, so that the overall tax schedule is regressive.

The results are somewhat similar for private schools, though the magnitude of the taxes generated by federal aid and institutional aid are more equal. Marginal federal aid taxes peak for low levels of cash assets at just over $1.5 \%$ per year and rapidly declined for high levels of assets, while marginal institutional aid taxes are less than $0.5 \%$ per year for low levels of cash assets and climb rapidly as assets increase. The upward spikes, which are due to the progressivity built into the EFC formulas, when combined with the progressive tax rates from the institution aid, produce a total financial aid tax schedule that tends to be progressive over the first $\$ 40,000$ in cash assets, and then becomes regressive because of the dramatic decline in the marginal rates due to federal aid.

Figure 6 shows the marginal tax rates produced by the allocation of all grants and by the allocation of all loans, for typical families in our samples. ${ }^{28}$ These figures show that it is the allocation of grants that produces most of the total financial aid tax. The marginal tax rates resulting from the allocation of loans are both small and relatively

\footnotetext{
${ }^{27}$ As in figures 2 and 3. we set family characteristics and school costs at their means.

${ }^{28} \mathrm{As}$ in figures 2 and 3 . we set family characteristics and school costs at their means.
} 
constant over ranges of assets holdings for typical families, although they are slightly over twice as high for private schools as for public schools. The marginal tax rates resulting from the allocation of grants, on the other hand, are both large and very different at different levels of cash assets. The strong downward slope in the marginal tax schedule for public schools is completely due to the allocation of grants and is, in fact, somewhat offset by loans. The story is similar for private schools, although not as stark.

One implication from the findings displayed in Figure 6 is that loans produce only a relatively small part of the total financial aid tax rate. Therefore, our decision to value a one dollar loan at only fifty cents does not greatly affect the results of sections 4 and 5 . Excluding them from AID VALUE or including them at full face value would produce similar results.

\section{Implications}

Previous calculations of the implicit taxes in college financial aid rely upon the assumption that aid equals financial need as determined by the federal need determination formula, or at least that decreases in need cause equal decreases in financial aid. We test and strongly reject both hypotheses.

We find that the actual financial aid taxes are smaller than those suggested by the federal need determination formulas. Nevertheless, they are large. For typical families, the marginal income tax ranges from $2 \%$ to $16 \%$ and the marginal asset tax ranges from about $10 \%$ to $25 \%$. These rates depend on the type of school a student attends, the cost of the school, and the family's financial means. In the school year we study, most of the financial aid tax is driven by the allocation of grants rather than loans.

The magnitude of these taxes raises concerns about both the horizontal equity and efficiency of the financial aid system. Horizontal inequalities arise if two families with similar characteristics and identical streams of income wind up paying different amounts for college education. The financial aid system creates exactly this situation if one of the 
above families saves for college expenses while the other consumes. In Section 5 , we estimate that the price difference can be over $\$ 20,000$

Such large disparities have the potential to distort savings decisions, though the extent to which families actually recognize these incentives and adjust their behavior remains unclear. Feldstein suggests that the impact on families asset accumulation is substantial, but as we discuss in Section 4, our findings bring his methodology into question. Future research should estimate the impact of aid taxes using the actual taxes faced by families, such as we have estimated here.

The extent to which financial aid taxes discourage savings has important policy implications. For instance, consider a policy that offers a tax deduction for education costs beyond high school, similar to that proposed by President Clinton in his State of the Union Address of January 1995. In effect, this policy would reduce the current financial aid tax by a fraction equal to the marginal federal income tax rate that the family faces. That is, if a family faces a $3 \%$ financial aid tax on assets for each of the eight years that it sends two children to college, then an additional dollar of savings would cause the college price to rise by nearly a quarter. Because the family's additional contribution would be tax deductible under the President's proposal, the federal government would pay a fraction of this additional burden equal to the family's federal marginal income tax rate. Thus, making education costs tax deductible would reduce the financial aid taxes, and would be an attractive policy alternative if the savings disincentives of financial aid taxes are large On the other hand, it must be recognized that the bilk of the subsidy for educational expenditure will go to those who pay most or all of their college bill, and not those who receive a great deal of aid.

Finally, our findings raise concerns about the vertical equity of the financial aid system. The federal need determination formula, which determines a family's expected contribution, was constructed to be progressive by increasing the contribution rates for higher means families. The progressivity of this formula, however, is undone by the way 
financial aid is distributed, and in particular by the way federal aid is distributed. (The progressivity of the discretionary aid awarded by schools mitigates this somewhat).

In the end, the regressivity of the financial aid system is similar to that of other means-based income support programs, such as Aid to Families with Dependent Children. Because these subsidies are sharply reduced as families earn additional income. it is common in the United States that those with the greatest need face the highest marginal tax rates. Although it is difficult to imagine modifying the federal aid policy to eliminate all regressive elements while continuing to give need-based financial aid. it may be possible to limit the horizontal inequities and minimize the savings disincentives. Ideally, need-based financial aid would be based only on permanent income, eliminating distortions. Although permanent income is not known, such an ideal could be approached if we required families to provide their full wage histories, which could then be verified using social security data. ${ }^{29}$ Then, aid could be based exclusively on these wage histories. This would eliminate the penalty for saving. Of course. such a system would simply amount to taxing wage income over a much longer period. However, this would minimize the distortions in labor supply by broadening the base of the tax and lowering tax rates.

\footnotetext{
${ }^{29}$ Although wage income data collected by the Social Security Administration is capped. they do retain the time of the year during which the cap was exceeded.
} 


\section{REFERENCES}

Brimelow, P., "Taxation Without Representation," Forbes, January: 17, 1994, pp. $74-75$.

Brown, Kathleen, "Building a New California: The Kathleen Brown Economic Plan 1994," (Campaign literature in California's $199+$ gubernatorial campaign).

Case, Karl E. and McPherson, Michael S., "Student Aid Incentives and Parental Effort: The Impact of Need-Based Aid on Savings and Labor Supply," technical report prepared for the Washington Office of the College Board, 1986.

Clements, Jonathan, "Saving for Your Children's College Costs? Here's a Primer," Wall Street Joumal, November 11, 1994, p. C1.

Dennis, Marguerite J., Keys to Financing a College Education. New York: Barron's, 1990.

Edlin, Aaron S., "Financing Higher Education: Inequitable and Inefficient? The Worst of All Possible Worlds," CEPR working paper. Stanford University, 1992.

Edlin, Aaron S., "Is College Financial Aid Equitable and Efficient?" Journal of Economic Perspectives, Spring 1993, 7:2, 143-158.

Feldstein, Martin, "College Scholarship Rules and Private Saving," The American Economic Review, June 1995, 85:3, 552-566.

Feldstein, Martin, "Why Capital Gains Taxes are Unfair," editorial page, Wall Street Journal, November 21, 1994.

McPherson, Michael S., and Morton Owen Schapiro, Keeping College Affordable: Government and Educational Opportunity. Washington, D.C.: The Brookings Institution, 1991.

Peterson's 1991 College Money Handbook. Princeton: Peterson, 1991.

Richman, Louis S., "How Americans Can Save More," Fortune, Fall 1993, p. 94-118.

Stoffel, Jennifer, "College Economics 101," Fidelity Focus: The Magazine for Fidelity Investors, Summer 1991, pp. 4-9. 
Venti, Steven F.. "The Allocation of Discretionary Grant Aid," in Manski, Charles F. and David A. Wise, College Choice in America. Cambridge: Harvard Lniversity Press, 1983.

U.S. Department of Education, National Center for Education Statistics, "Quality of Responses in the 1987 National Postsecondary Student Aid Study." NCES 93$446,1993$.

U.S. Department of Education, Office of Student Financial Assistance, "The Congressional Methodology, 1990-91," 1990.

U.S. Department of Education, "Federal Pell Grant Program Schedule for Determining Full-Time Scheduled Awards for the 1994-95 Award Period."

L.S. Department of Education, Student Financial Assistance Programs. Counselor's Handbook for Postsecondary Schools 1994-95, 1994

U.S. News \& World Report, "How to Pay for College", October 3. 1994. pp. $70-73$. 
Table 1: Aid Breakdown by Income

\begin{tabular}{l|rr}
\multicolumn{3}{c}{ Mean Aid } \\
\hline Parental Income & TOTAL AID & AID VALUE \\
\hline $0<$ income $<\$ 10,000$ & $\$ 5039$ & $\$+124$ \\
$\$ 10,000<$ income $<\$ 20,000$ & $\$ 4930$ & $\$ 3904$ \\
$\$ 20,000<$ income $<\$ 30,000$ & $\$ 4581$ & $\$ 3518$ \\
$\$ 30,000<$ income $<\$ 40,000$ & $\$ 3924$ & $\$ 2923$ \\
$\$ 40.000<$ income $<\$ 50,000$ & $\$ 3451$ & $\$ 2562$ \\
$\$ 50,000<$ income $<\$ 60,000$ & $\$ 3066$ & $\$ 2245$ \\
$\$ 60,000<$ income $<\$ 70,000$ & $\$ 2837$ & $\$ 2107$ \\
$\$ 70,000<$ income $<\$ 80.000$ & $\$ 2620$ & $\$ 1941$ \\
$\$ 80.000<$ income $<\$ 90,000$ & $\$ 2686$ & $\$ 2120$ \\
$\$ 90,000<$ income $<\$ 100,000$ & $\$ 2426$ & $\$ 1922$ \\
income $>\$ 100.000$ & $\$ 2029$ & $\$ 1450$
\end{tabular}

Table 2: Aid Breakdown by Assets

\begin{tabular}{|c|c|c|}
\hline \multicolumn{3}{|c|}{ Mean Aid } \\
\hline Parental Assets & TOTAL AID & AID VALUE \\
\hline $0<$ assets $<\$ 10,000$ & 55344 & $\$+217$ \\
\hline$\$ 10,000<$ assets $<\$ 20,000$ & $\$ 5070$ & $\$ 3910$ \\
\hline$\$ 20,000<$ assets $<\$ 30,000$ & $\$ 4773$ & $\$ 3616$ \\
\hline$\$ 30,000<$ assets $<\$ 40,000$ & $\$ 4745$ & $\$ 3577$ \\
\hline$\$ 40,000<$ assets $<\$ 50,000$ & $\$ 4786$ & $\$ 3664$ \\
\hline$\$ 50,000<$ assets $<\$ 60,000$ & $\$ 4664$ & $\$ 3525$ \\
\hline $\mathbf{\$} 60,000<$ assets $<\$ 70,000$ & $\$ 4640$ & $\$ 3505$ \\
\hline$\$ 70,000<$ assets $<\$ 80,000$ & $\$ 4432$ & $\$ 3396$ \\
\hline$\$ 80,000<$ assets $<\$ 90,000$ & $\$ 3838$ & $\$ 2892$ \\
\hline$\$ 90,000<$ assets $<\$ 100,000$ & $\$ 4136$ & $\$ 3128$ \\
\hline assets $>\$ 100,000$ & $\$ 3208$ & $\$ 2387$ \\
\hline
\end{tabular}




\section{Table 3: Summary Statistics}

Sample Used in Section Four

\begin{tabular}{l|rrrr|rrrr}
\hline & \multicolumn{3}{|c|}{ Public Schools, $N=2349$} & \multicolumn{3}{c}{ Private Schoois. $N=4188$} \\
& Mean & Stu. Dev. & Min. & Mlax & Mean & Std Dev & Min. & Max. \\
\hline \multirow{2}{*}{ AID VALUE } & $\$ 2.263 .53$ & $\$ 1.61+62$ & $\$ 0.00$ & $\$ 17.433 .50$ & $\$ 5.006 .38$ & $\$ 3.384 .31$ & $\$ 0.00$ & $\$ 26.590 .00$ \\
EFC & $\$ 1.941 .30$ & $\$ 1.507 .86$ & $\$ 700.00$ & $\$ 12.010 .00$ & $\$ 3.794 .29$ & $\$ 3.109 .94$ & $\$ 700.00$ & $\$ 21.080 .00$ \\
COST & $\$ 5.069 .81$ & $\$ 2.359 .39$ & $\$ 810.00$ & $\$ 18.712 .00$ & $\$ 10.78285$ & $\$ 3.958 .54$ & $\$ 1.025 .00$ & $\$ 28.631 .00$
\end{tabular}

Sample Used in Section Five

\begin{tabular}{|c|c|c|c|c|c|c|c|c|}
\hline & \multicolumn{4}{|c|}{ Public Schools. $N=1668$} & \multicolumn{4}{|c|}{ Private Schools. $V=3180$} \\
\hline & Mean & Std. Dev. & Min. & Max. & Mean & Std Dev & Min. & Max. \\
\hline AID VALLE & $\$ 2.408 .30$ & $\$ 1.481 .26$ & $\$ 0.00$ & $\$ 15.917 .00$ & $55.2+1.11$ & $\$ 3.240 .27$ & $\$ 0.00$ & $\$ 23 . \$ 60.00$ \\
\hline EFC & $\$ 1.857 .95$ & $\$ 1.386 .97$ & $\$ 700.00$ & $\$ 12.010 .00$ & $\$ 3.637 .97$ & $\$ 2.978 .19$ & $\$ 700.00$ & $\$ 19.360 .00$ \\
\hline $\operatorname{cosT}$ & $\$ 5.042 .97$ & 52.374 .33 & $\$ 810.00$ & $\$ 18.712 .00$ & $\$ 10.782 .87$ & $\$ 3,938.43$ & 51.025 .00 & $\$ 28.170 .00$ \\
\hline Male & $0 .+15$ & 0.497 & 0 & 1 & 0.46 & 0.499 & 0 & 1 \\
\hline \multicolumn{9}{|l|}{ Race } \\
\hline Native Am. & 0.005 & 0.073 & 0 & 1 & 0.006 & 0.075 & 0 & 1 \\
\hline Asian & 0.044 & 0.206 & 0 & 1 & 0.04 & 0.205 & 0 & 1 \\
\hline Black & 0.177 & 0.382 & 0 & 1 & 0.091 & 0.287 & 0 & 1 \\
\hline Hispanic & 0.064 & 0.244 & 0 & 1 & 0.045 & 0.207 & 0 & 1 \\
\hline \multicolumn{9}{|l|}{ Marital Stanus } \\
\hline Married & 0.015 & 0.122 & 0 & 1 & 0.012 & 0.110 & 0 & 1 \\
\hline Separated & 0.001 & 0.035 & 0 & 1 & 0.001 & 0.025 & 0 & 1 \\
\hline \multicolumn{9}{|l|}{ Residence } \\
\hline Off Campus & 0.239 & 0.427 & 0 & 1 & 0.110 & 0.313 & 0 & 1 \\
\hline Parents & 0.244 & 0.430 & 0 & 1 & 0.192 & 0.394 & 0 & 1 \\
\hline \multicolumn{9}{|l|}{ H.S. Degree } \\
\hline GED & 0.008 & 0.088 & 0 & 1 & 0.004 & 0.064 & 0 & 1 \\
\hline Certificate & 0.016 & 0.124 & 0 & 1 & 0.006 & 0.075 & 0 & 1 \\
\hline None & 0.007 & 0.085 & 0 & 1 & 0.007 & 0.081 & 0 & 1 \\
\hline \multicolumn{9}{|l|}{ Parents' Assets } \\
\hline Cash & $\$ 2.536 .07$ & $\$ 6.742 .08$ & $\$ 0.00$ & $\$ 83,000.00$ & $\$ 4,476.25$ & $\$ 12,315.08$ & $\$ 0.00$ & $\$ 338,427.00$ \\
\hline Home Equiry & $\$ 22,841.4$ & $\$ 24.839 .21$ & $\$ 0.00$ & $\$ 220,000.00$ & $\$ 35,151.71$ & $\$ 37,383.31$ & $\$ 0.00$ & $\$ 660,000.00$ \\
\hline Other & $\$ 3.059 .39$ & $\$ 11.457 .38$ & $\$ 0.00$ & $\$ 132,563.00$ & $\$ 7,326.40$ & $\$ 23,090.72$ & $\$ 0.00$ & $\$ 445,000.00$ \\
\hline Business & $\$ 4.245 .72$ & $\$ 20.123 .03$ & $\$ 0.00$ & $\$ 490.000 .00$ & $\$ 4,210.53$ & $\$ 21,085.53$ & $\$ 0.00$ & $\$ 435,000.00$ \\
\hline Parents' Income & $\$ 21,150.1$ & $\$ 12.685 .59$ & $\$ 0.00$ & $\$ 84.323 .00$ & $\$ 30.751 .79$ & $\$ 17.259 .42$ & $\$ 0.00$ & $\$ 129,769.00$ \\
\hline
\end{tabular}


Table 4: Aid Value for Applicants with Need >0

Dependent Variable: Aid Value

\begin{tabular}{|c|c|c|c|c|c|c|c|c|}
\hline \multirow[b]{3}{*}{ Variable } & \multicolumn{4}{|c|}{ Private Schools } & \multicolumn{4}{|c|}{ Public Schools } \\
\hline & \multicolumn{2}{|c|}{ OLS } & \multicolumn{2}{|c|}{ Tobit } & \multicolumn{2}{|c|}{ OLS } & \multicolumn{2}{|c|}{ Tobit } \\
\hline & Coefficient & t-stat & Coeflicient & 1-stiat & Coeflicient & t-slat & Coefficient & 1-stat \\
\hline Constant & $4.95 \mathrm{e}+03$ & 9.86 & $4.86 \mathrm{e}+03$ & 9.38 & $2.34 \mathrm{e}+03$ & 12.76 & $2.27 \mathrm{e}+0.3$ & 11.02 \\
\hline EFC & $-4.55 e-01$ & -8.28 & $-4.41 \mathrm{e}-01$ & -7.66 & $-9.28 \mathrm{e}-01$ & -6.42 & $-9.19 \mathrm{e}-01$ & -5.80 \\
\hline $\operatorname{cost}$ & $-3.9|e-0|$ & -2.87 & $-3.89 \mathrm{e}-01$ & -2.75 & $2.98 \mathrm{e}-(1)$ & 9.51 & $3.05 \mathrm{e}-01$ & 9.32 \\
\hline $\mathrm{EFC}^{\wedge} 2$ & $2.46 \mathrm{e}-05$ & 5.57 & $2.18 \mathrm{e}-0.5$ & 4.71 & $1.49 \mathrm{e}-0.4$ & 3.99 & $1.41 \mathrm{e}-0.4$ & 3.42 \\
\hline $\operatorname{cosT}^{\wedge} 2$ & $7.92 e-05$ & 6.93 & $7.96 \mathrm{e}-05$ & 6.73 & $-6.75 e-06$ & -3.46 & $-7.18 \mathrm{e}-06$ & -3.56 \\
\hline $\mathrm{EFC} * \mathrm{COST}$ & $-2.31 e-05$ & -4.52 & $-2.28 \mathrm{e}-05$ & -4.31 & $-2.73 e-05$ & -2.96 & $-2.60 \mathrm{e}-05$ & -2.64 \\
\hline $\operatorname{cosT}^{\wedge} 3$ & $-2.22 e-09$ & -7.6 .3 & $-2.25 e-09$ & -7.44 & & & & \\
\hline $\mathrm{EFC}^{\wedge} 3$ & & & & & $-6.05 e-09$ & -2.11 & $-5.78 \mathrm{e}-09$ & -1.82 \\
\hline Sigma & & & $3.00 \mathrm{e}+03$ & 89.14 & & & $1.58 \mathrm{e}+03$ & 65.14 \\
\hline Log-likelihood & -39346.1 & & -38268.7 & & -23327.9 & & -21889.4 & \\
\hline Number of obs. & 4188 & & 4188 & & 2669 & & 2669 & \\
\hline Number w/ zero aid & 146 & & 146 & & 211 & & 211 & \\
\hline Adjusted R-squared & 0.259 & & & & 0.133 & & & \\
\hline
\end{tabular}


Table 5: Aid Value for Applicants with Need > I

Dependent Variable: Aid Valuc

\begin{tabular}{|c|c|c|c|c|c|c|c|c|}
\hline \multirow[b]{3}{*}{ Variable $^{\prime}$} & \multicolumn{4}{|c|}{ Private Sclıools } & \multicolumn{4}{|c|}{ Public Schools } \\
\hline & \multicolumn{2}{|c|}{ OLS } & \multicolumn{2}{|c|}{ Tobit } & \multicolumn{2}{|c|}{ Ols } & \multicolumn{2}{|c|}{ Tobit } \\
\hline & Coefficient & t-stat & Coefficient & $1-s t a t$ & Coefficient & t-stat & Coefficient & i-stat \\
\hline Constant & $6.93 e+03$ & 12.85 & $6.93 e+03$ & 12.70 & $3.30 \mathrm{e}+03$ & 16.99 & $3.33 \mathrm{e}+03$ & 16.06 \\
\hline EFC & $-2.37 e-01$ & -3.29 & $-2.14 \mathrm{e}-01$ & -2.90 & $-8.02 \mathrm{e}-01$ & -5.15 & $-8.59 \mathrm{e}-01$ & -4.81 \\
\hline $\cos T$ & $-6.97 e-01$ & -4.80 & $-6.94 \mathrm{e}-01$ & -4.72 & $2.35 e-01$ & 5.24 & $2.39 \mathrm{e}-01$ & 5.19 \\
\hline $\mathrm{EFC}^{\wedge} 2$ & $1.77 \mathrm{e}-05$ & 3.42 & $1.55 \mathrm{e}-05$ & 2.94 & $1.54 \mathrm{e}-0.4$ & 3.87 & $1.73 e-04$ & 3.59 \\
\hline $\operatorname{cosT}^{\wedge} 2$ & $1.02 \mathrm{e}-04$ & 8.26 & $1.01 \mathrm{e}-04$ & 8.16 & $-7.20 e-06$ & -2.14 & $-7.55 e-06$ & -2.19 \\
\hline $\mathrm{EFC}^{*} \mathrm{COST}$ & $-2.25 \mathrm{e}-05$ & -4.04 & $-2.21 \mathrm{e}-05$ & -3.94 & $-1.68 \mathrm{e}-0.5$ & -1.37 & $-1.56 e-05$ & -1.23 \\
\hline $\operatorname{cosT}^{\wedge} 3$ & $-2.76 e-09$ & -8.69 & $-2.76 \mathrm{e}-09$ & -8.59 & & & & \\
\hline $\mathrm{EFC}^{\wedge} 3$ & & & & & $-7.88 \mathrm{e}-09$ & -2.83 & $-9.97 e-09$ & -2.69 \\
\hline Parents' Money & $-8.75 e-03$ & -2.20 & $-9.32 e-03$ & -2.31 & $-1.47 e-02$ & -3.06 & $-1.59 \mathrm{e}-02$ & -3.19 \\
\hline Parents' Home & $-4.51 e-03$ & -3.06 & $-5.02 \mathrm{e}-03$ & -3.3 .5 & $-5.61 \mathrm{e}-0.3$ & -3.98 & $-5.89 e-03$ & -4.06 \\
\hline Parents' Other & $-1.10 \mathrm{e}-02$ & -5.00 & $-1.2 / \mathrm{e}-02$ & -5.30 & $-3.88 c-0.3$ & -1.36 & $-4.71 \mathrm{e}-0) 3$ & -1.60 \\
\hline Parents' Business & $-4.22 e-03$ & -1.86 & $-4.94 e-03$ & -2.12 & $-1.82 e-03$ & -1.12 & $-1.86 e-03$ & -1.12 \\
\hline Income & $-2.43 e-02$ & -5.41 & $-2.60 \mathrm{e}-02$ & -5.69 & $-2.36 e-02$ & -5.88 & $-2.39 \mathrm{e}-02$ & -5.77 \\
\hline Sigma & & & $2.68 e+03$ & 78.77 & & & $1.31 \mathrm{e}+03$ & 56.13 \\
\hline I.og-likelihood & -29576.1 & & -29179.7 & & -14284.2 & & -13871.2 & \\
\hline Number of obs. & 3180 & & 3180 & & 1668 & & 1668 & \\
\hline Number w/ zero aid & 54 & & 54 & & 63 & & 63 & \\
\hline Adjusted R-squared & 0.327 & & & & 0.257 & & & \\
\hline
\end{tabular}

'Regression controls for race, gender, marital status, living arrangements, and high school education. 
Figure 1

Rate of Meeting Marginal Need
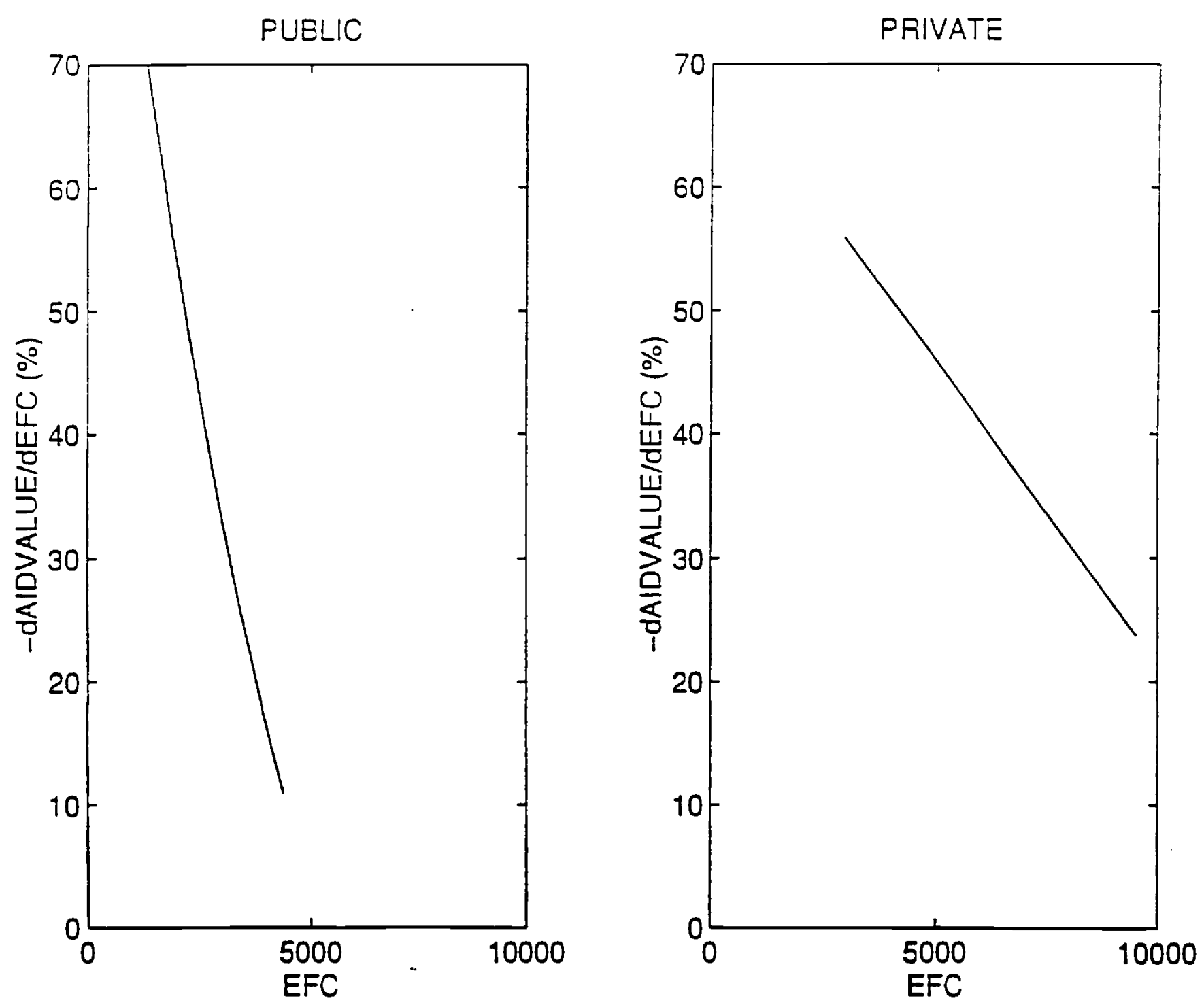

We set the cost of public schools at $\$ 5.070$ and the cost of private schools at $\$ 10,783$. their mean values in the sample we use in Section 4. 
Figure 2

Marginal Yearly Tax on Cash Assets

PUBLIC

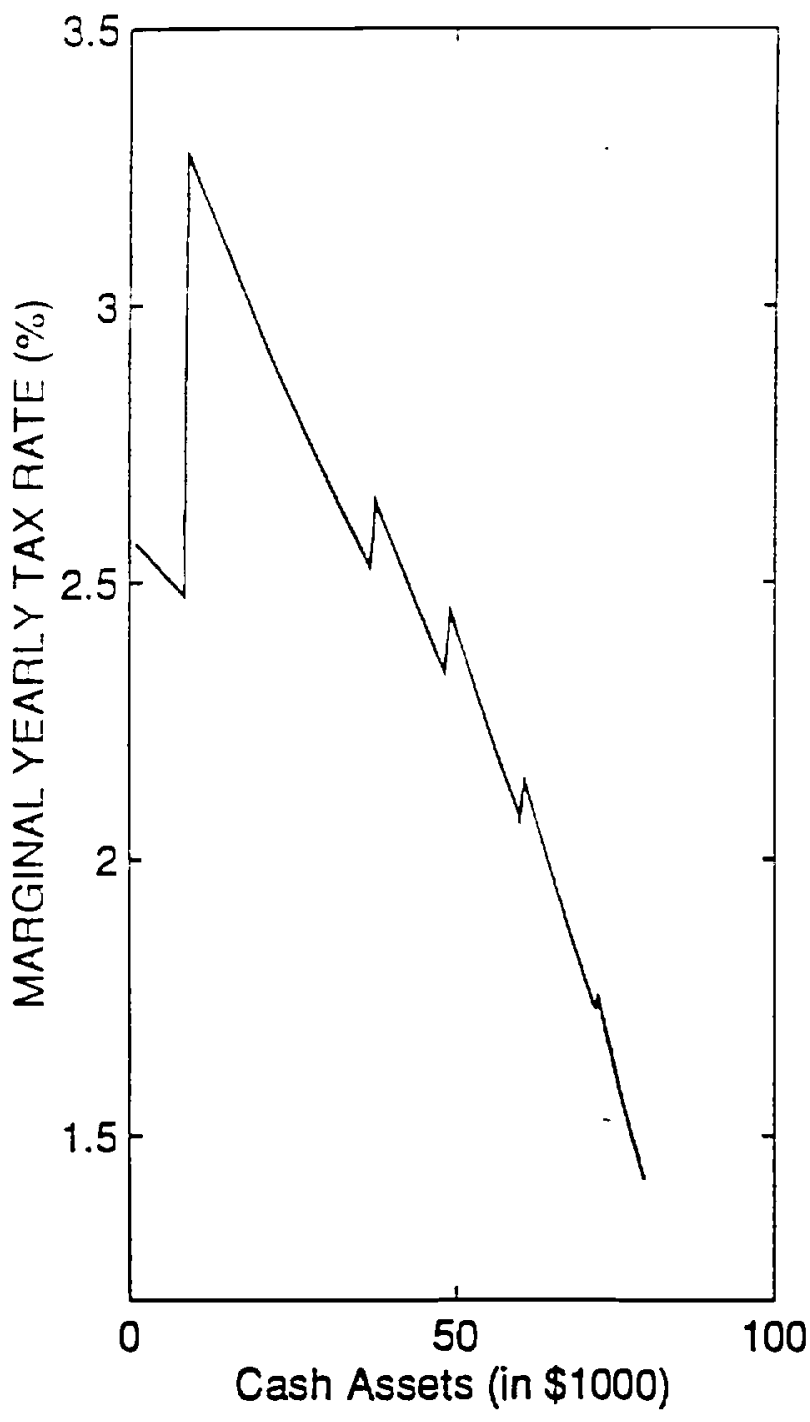

PRIVATE

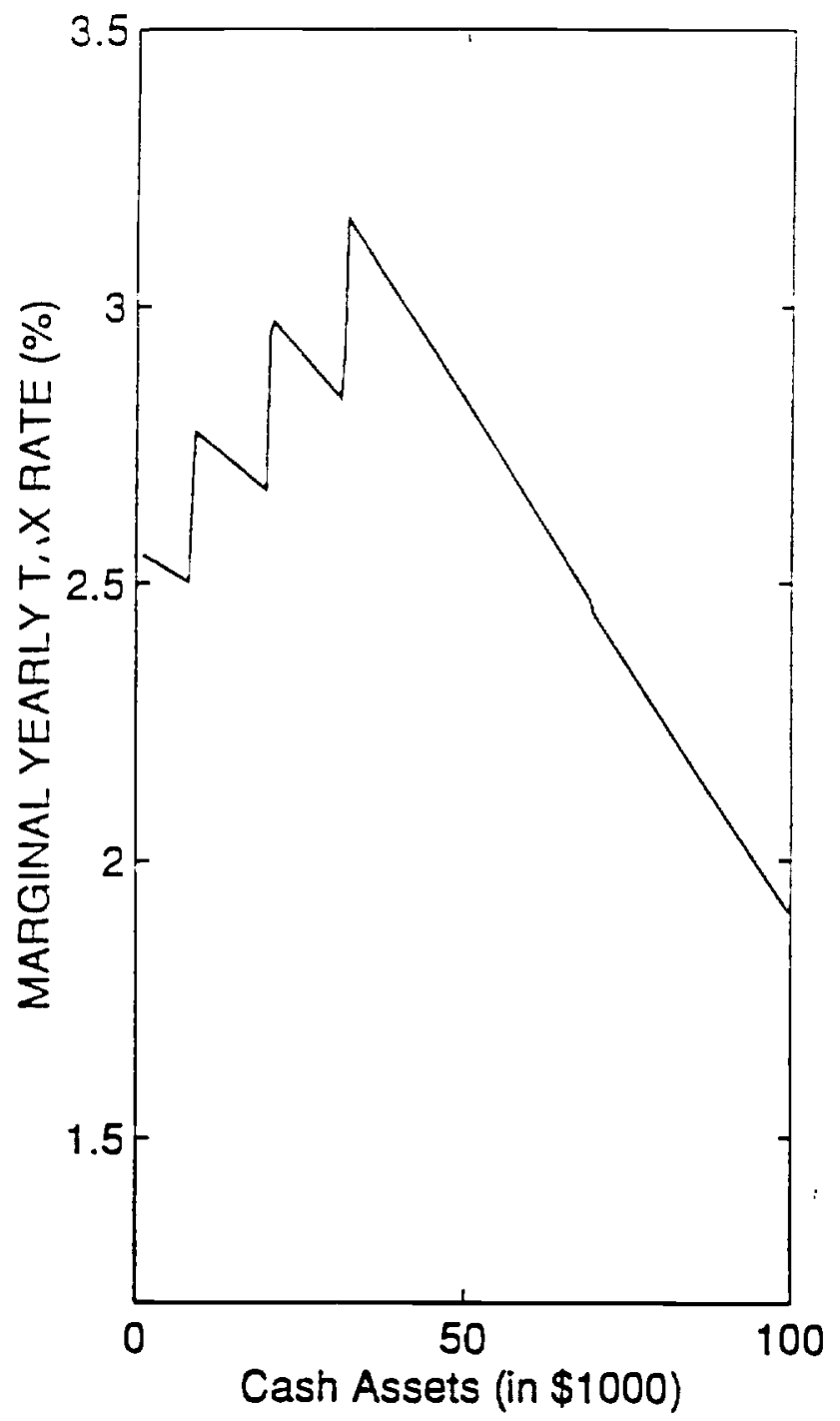

We assume cash assets eam $5 \%$ interest and the family has one wage earner. We set home equity, other assets, business assets, earned income, and school costs at their mean values for public and private schools in our Section 5 sample. Mean values for home equity are $\$ 22.841$ and $\$ 35.152$ for public and private schools, respectively. Mean values for other assets are $\$ 3,059$ and $\$ 7,326$ for public and private schools, respectively. Mean values for business assets are $\$ 4,246$ and $\$ 4,211$ for public and private schools. respectively. Mean values for income are $\$ 21,150$ and $\$ 30,752$ for public and private schools, respectively. Mean values for school costs are $\$ 5,043$ and $\$ 10,78.3$ for public and private schools, respectively. 
Figure 3

Marginal Income Tax
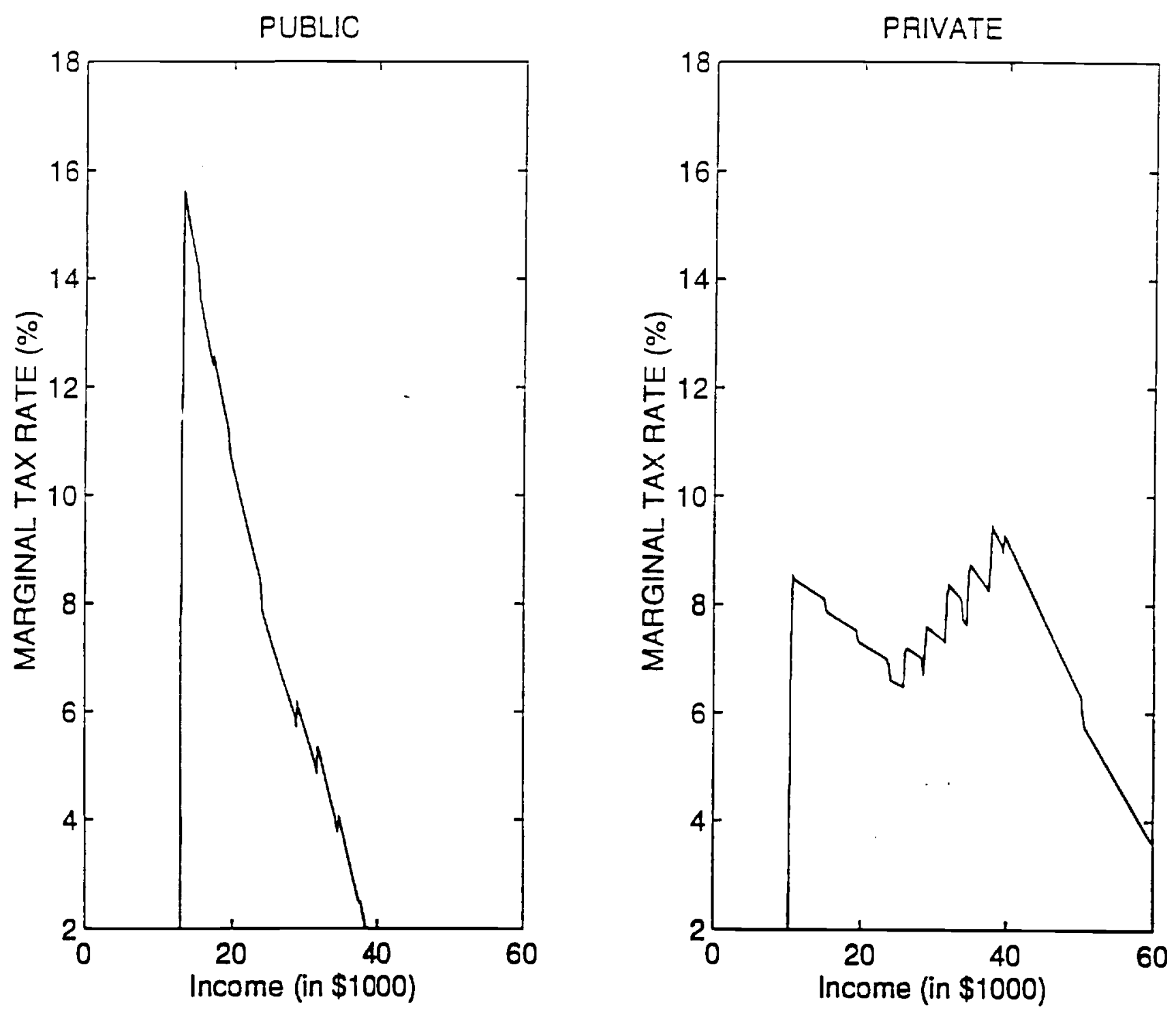

We assume cash assets earn $5 \%$ interest and the family has one wage earner. We set cash assets, home equity, other assets, business assets and school costs at their mean values for pijblic and private schools in our Section 5 sample. Mean values for cash assets are $\$ 2,536$ and $\$ 4,476$ for public and private schools, respectively. Mean values for home equity are $\$ 22.841$ and $\$ 35.152$ for publlc and private schools, respectively. Mean values for other assets are $\$ 3,059$ and $\$ 7,326$ for public and private schools, respectively. Mean values for business assets are $\$ 4,246$ and $\$ 4,211$ for public and private schools, respectively. Mean values for school costs are $\$ 5,043$ and $\$ 10,783$ for public and private schools, respectively. 


\section{Figure 4 \\ Marginal Subsidy for Educational Expenditures}

PUBLIC

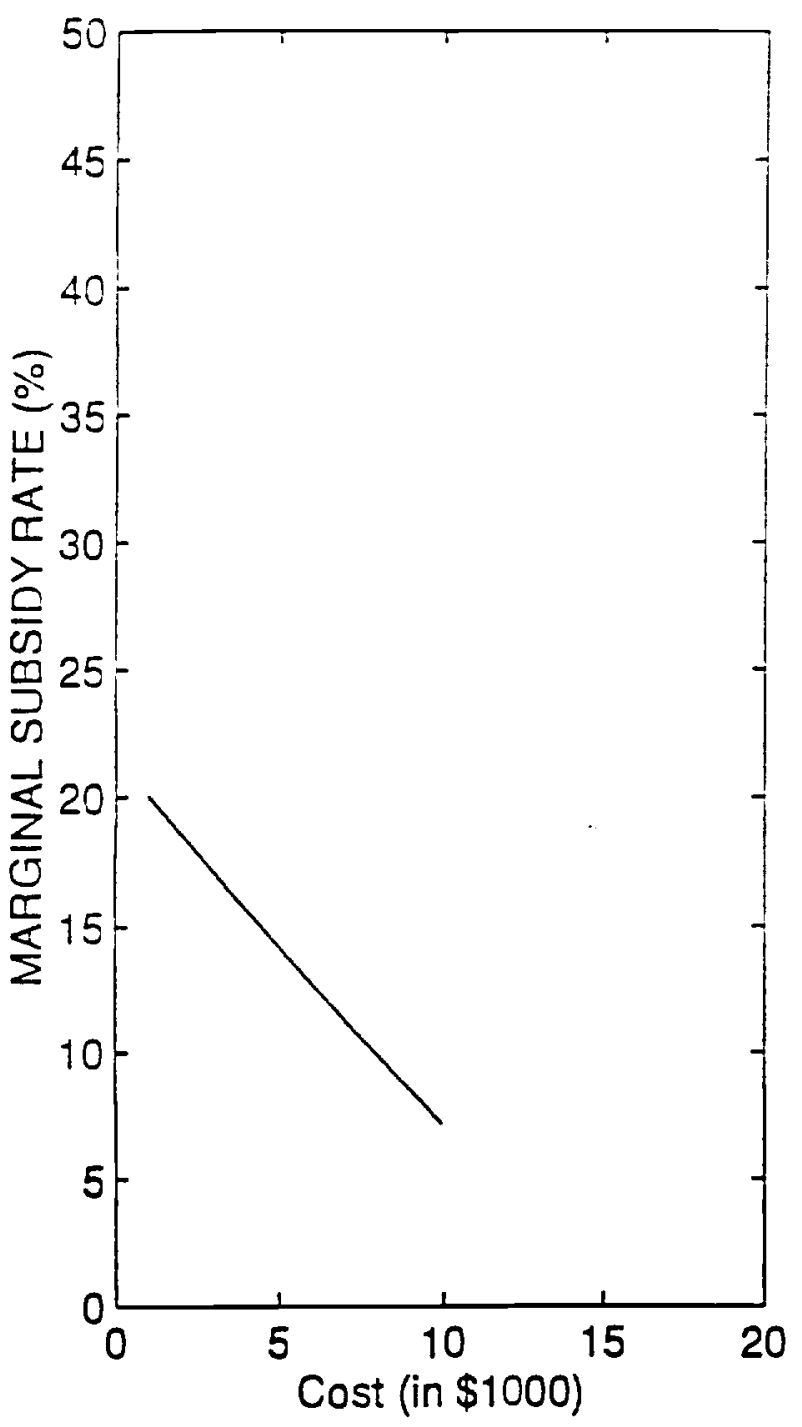

PRIVATE

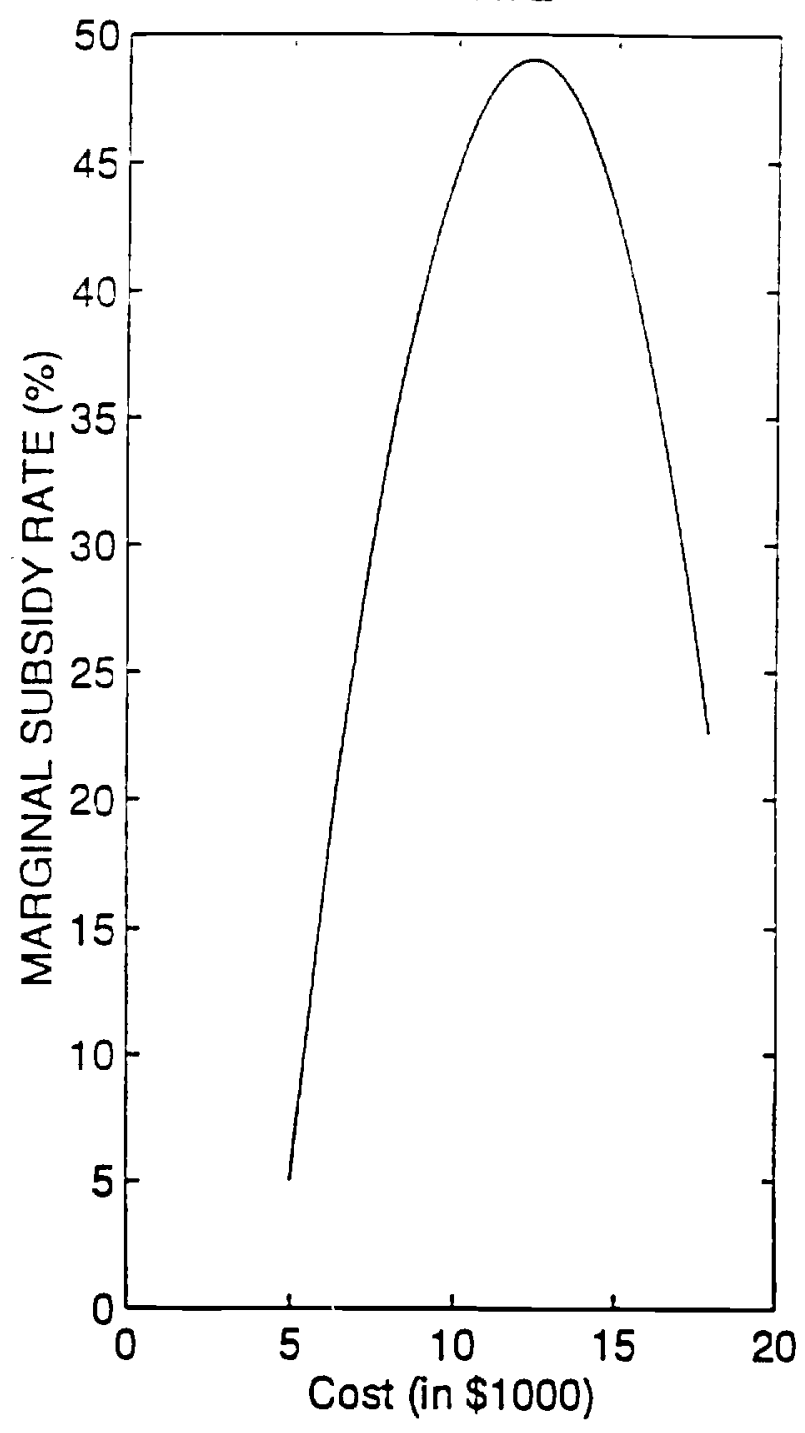

We assume cash assets earn $5 \%$ interest and the family has one wage eamer. We set cash assets. home equity, other assets, business assets, and earned income at their mean values for public and private schools in our Section 5 sample. Mean values for cash assets are $\$ 2.536$ and $\$ 4,476$ for public and private schools, respectively. Mean values for home equity are $\$ 22,841$ and $\$ 35,152$ for public and private schools. respectively. Mean values for other assets are $\$ 3,059$ and $\$ 7,326$ for public and private schools, respectively. Mean values for business assets are $\$ 4,246$ and $\$ 4,211$ for public and private schools. respectively. Mean values for income are $\$ 21,150$ and $\$ 30.752$ for public and private schools, respectively. 
Figure 5

Marginal Yearly Tax on Cash Assets by Source of Aid
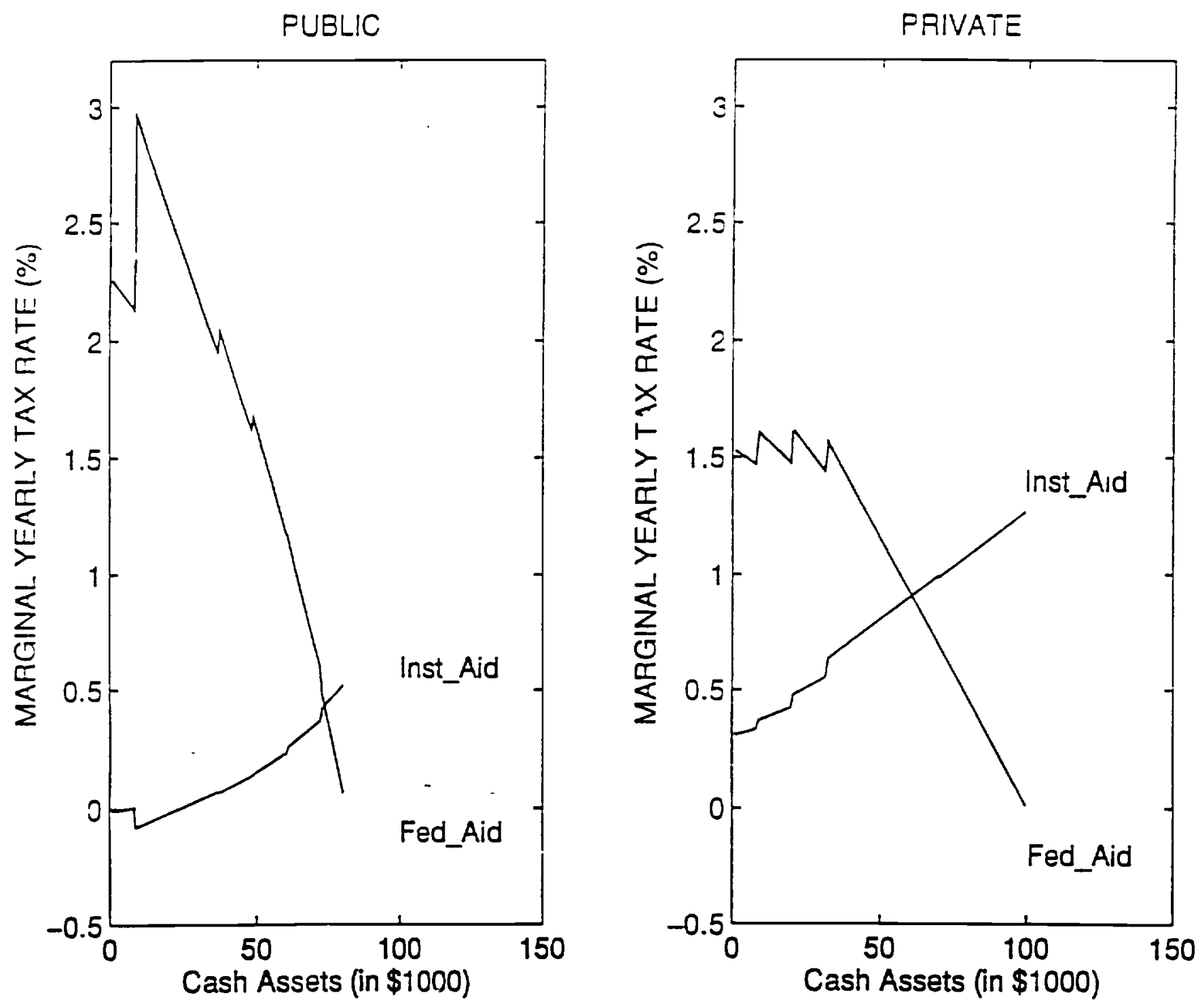

We assume cash assets earn $5 \%$ interest and the family has one wage earner. We set home equity, other assets, business assets, eamed income, and school costs at their mean values for public and private schools in our Section 5 sample. Mean values for home equity are $\$ 22,841$ and $\$ 35,152$ for public and private schools. respectively. Mean values for other assets are $\$ 3,059$ and $\$ 7,326$ for public and private schools, respectively. Mean values for business assets are $\$ 4,246$ and $\$ 4,211$ for public and private schools, respectively. Mean values for income are $\$ 21,150$ and $\$ 30,752$ for public and private schools, respectively. Mean values for school costs are $\$ 5.043$ and $\$ 10,783$ for public and private schools, respectively. 
Figure 6

Marginal Yearly Tax on Cash Assets by Type of Aid

FUELIC

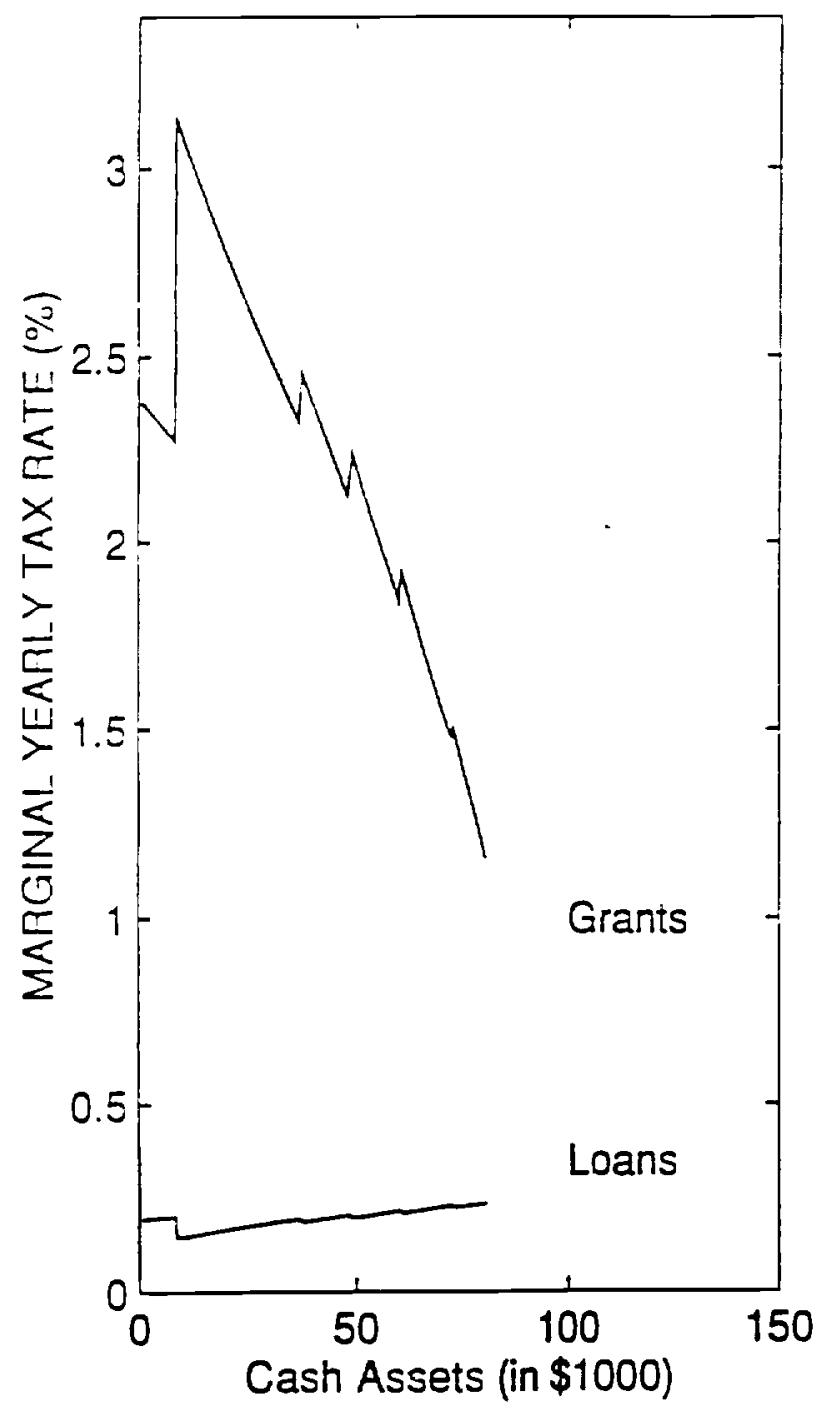

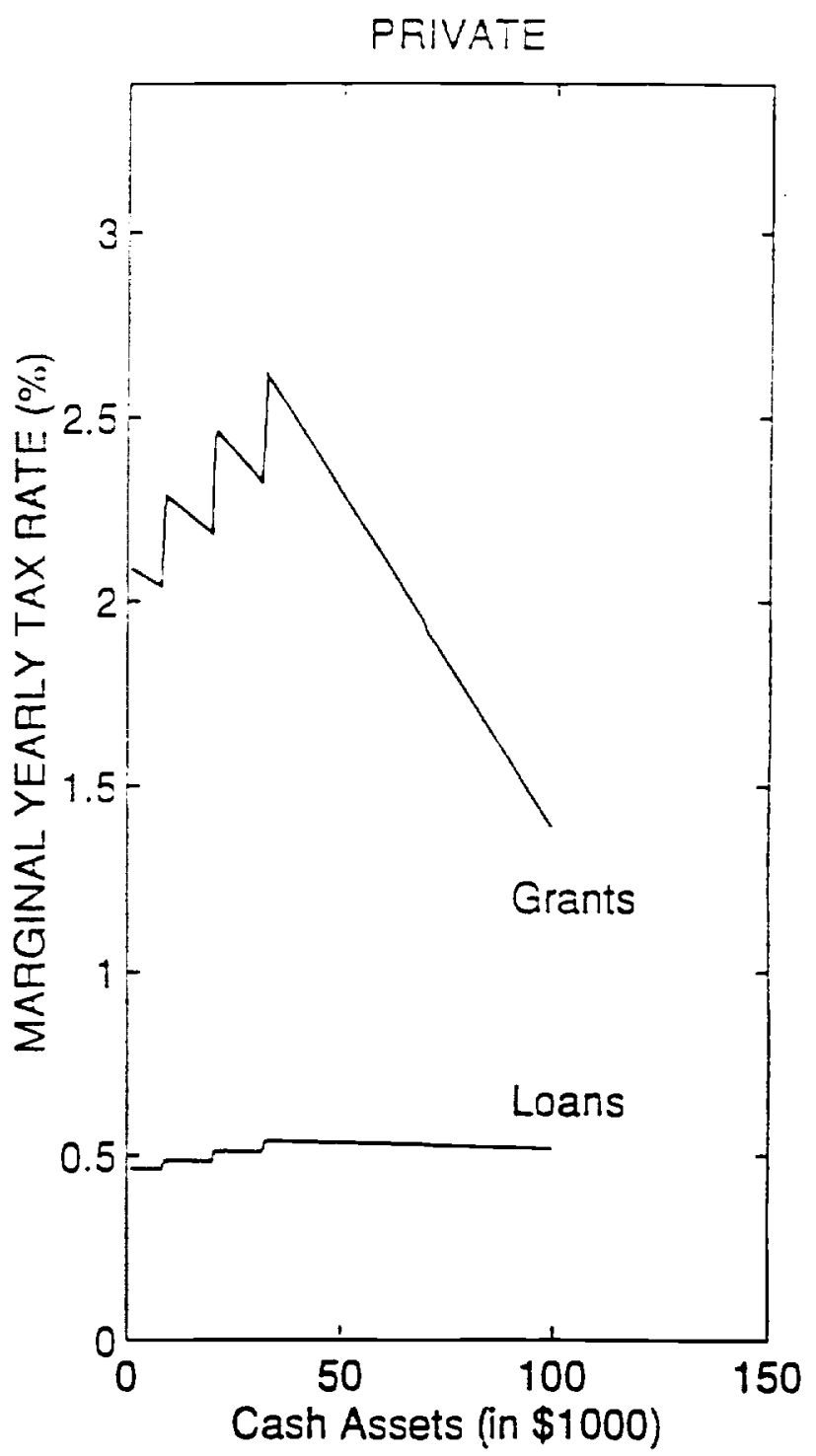

We assume cash assets eam $5 \%$ interest and the family has one wage eamer. We set home equity, other assets, business assets, earned income, and school costs at their mean values for public and private schools in our Section 5 sample. Mean values for home equity are $\$ 22.841$ and $\$ 35,152$ for public and private schools, respectively. Mean values for other assets are $\$ 3.059$ and $\$ 7.326$ for public and private schools. respectively. Mean values for business assets are $\$ 4,246$ and $\$ 4,21\}$ for public and private schools. respectively. Mean values for income are $\$ 21,150$ and $\$ 30,752$ for public and private schools, respectively. Mean values for school costs are $\$ 5.043$ and $\$ 10.783$ for public and private schools, respectively. 